\title{
PRIVATISASI BUMN DI INDONESIA
}

\author{
Syanti Dewi ${ }^{1}$ \\ ${ }^{1}$ Jurusan Akuntansi Fakultas Ekonomi Universitas Tarumanagara \\ syand3w1@yahoo.com
}

\begin{abstract}
ABSTRAK
Privatisasi dipilih menjadi jalan keluar kendala pertumbuhan PDB Indonesia. Dengan privatisasi diharapkan kinerjaBUMN meningkat dan akan menciptakan lapangan kerja dan meningkatkan PDB. Akuntansi sektor publik pada BUMN mengalami perubahan besar dengan dilakukannya privatisasi BUMN. Penelitian ini dimaksudkan untuk menguji apakah BUMN akan dapat meningkatkan perekonomian di Indonesia melalui privatisasi. Model Regresi Variabel Dummy digunakan untuk menganalisis data guna menguji pengaruh privatisasi terhadap peningkatan profitabilitas, efisiensi operasional, investasi, output, dan solvabilitas BUMN Non-Bank dan Bank BUMN di Indonesia. Hasilnya bahwa privatisasi hanya signifikan positif mempengaruhi investasi dan output BUMN non-bank, namun signifikan negatif mempengaruhi solvabilitas BUMN non-bank. Sementara privatisasi tidak signifikan positif mempengaruhi profitabilitas, efisiensi operasional, investasi, output, dan solvabilitas Bank BUMN dan tidak signifikan positif mempengaruhi profitabilitas BUMN non-Bank. Temuan penelitian ternyata privatisasi sesuai dengan rencana pemerintah Indonesia untuk membangun perekonomian melalui BUMN non-bank, dengan cara privatisasi BUMN Indonesia.
\end{abstract}

Kata kunci: Privatisasi, BUMN, PDB, investasi, dan output

\section{PENDAhuluan}

\section{Latar Belakang Masalah}

Pemerintah Indonesia sedang mengembangkan infrastruktur di Indonesia agar meningkatkan Produk Domestik Bruto (PDB). Mengingat kebijakan fiskal terkendala dengan sumber dana dari pajak maka pemerintah Indonesia menggunakan Badan Usaha Milik Negara (BUMN) guna mengembangkan PDB Indonesia, namun BUMN terkendala dengan kinerja nya yang masih diragukan. Oleh karena itu Privatisasi dipilih menjadi jalan keluar kendala tersebut. Dengan privatisasi diharapkan kinerjaBUMN meningkat dan akan menciptakan lapangan kerja dan meningkatkan PDB.

Akuntansi sektor publik pada BUMN mengalami perubahan besar dengan dilakukannya privatisasi BUMN. Pemerintah Indonesia melalui menteri BUMN sedang mempersiapkan privatisasi beberapa BUMN. Hal ini dipandang merupakan langkah terbaik untuk meningkatkan efisiensi. Literatur penelitian mendokumentasikan hal yang berbeda. Privatisasi merupakan langkah terbaik yang dapat dilakukan untuk meningkatkan efisiensi dengan menjalankan dua strategi utama yang tidak menghilangkan kontrol negara terhadap BUMN, yaitu akuisisi asing atau pencatatan saham di bursa saham ( Luo dan Yao, 2009: 2). Sementara itu privatisasi di United Kingdom dan beberapa Negara lain dilakukan oleh banyak perusahaan yang kesulitan pinjaman dan tidak dapat menghasilkan dana internal yang cukup untuk pertumbuhan sehingga go public merupakan satusatunya jalan untuk mendapatkan dana guna membiayai investasi perusahaan tersebut dan untuk mempertahankan peningkatan produksinya (Albornoz dan Pope, 2004: 25; Clementi, 2002: 2).

Alasan privatisasi lainnya perusahaan yang go public tumbuh lebih cepat, memperoleh keuntungan yang lebih tinggi, dan tingkat investasi pada aset yang lebih tinggi. Privatisasi bank pemerintah mempermudah akuisisi di masa depan dengan menggunakan tambahan modal yang berasal dari IPO untuk membiayai sebagian atau keseluruhan akuisisi. ( Rosen, Smart, dan Zutter, 2005: 4)

Keputusan perusahaan untuk go public dapat didasari oleh banyak motivasi, yaitu diversifikasi kepemilikan pengusaha, meningkatkan modal untuk investasi, mengeksploitasi kondisi pasar yang menguntungan, memfasilitasi akuisisi, meningkatkan likuiditas saham perusahaan, menemukan 
nilai pasar perusahaan, dan membuat perusahaan lebih dikenal (Pastor, Taylor, dan Veronesi, 2006: 1).

Privatisasi mempunyai hubungan positif dan signifikan terhadap profitabilitas perusahaan (. Katz, 2008; Huang dan Yao, 2006; Chong et.al, 2003; Tran, 2008; Beck, Cull, dan Jerome, 2005; Torero, 2003; Jain dan Kini, 2008; Shelor dan Anderson, 1998; Konings, Cayseele, dan Warzynski, 2002; Chong et.al, 2003; Hanousek, Kočenda, dan Švejnar, 2005; Hanousek, Kočenda, dan Švejnar, 2004; Omran, 2009; Galiani, Gertler, Schargrodsky, dan Sturzenegger, 2003; dan Bornstein, 2000). Namun demikian, Bozo, Machicado, dan Capra (2003) menemukan bahwa privatisasi tidak signifikan mempengaruhi profitabilitas perusahaan, serta temuan Pastor, Taylor, dan Veronesi (2006); Clementi (2002); Rosen, Smart, dan Zutter (2005); Bonin, Hasan, dan Wachtel (2004); Halkos dan Salamouris (2002); dan Quan dan Huyghebaert (2004), privatisasi signifikan mempunyai hubungan negatif terhadap profitabilitas perusahaan.

Variabel yang kedua adalah efisiensi operasional, efisiensi operasional meningkat signifikan setelah melakukan privatisasi ( Tran, 2008; . Torero, 2003; Galiani, Gertler, Schargrodsky, dan Sturzenegger, 2003), Sedangkan Huang dan Yao (2006) mendokumentasikan privatisasi signifikan mempunyai hubungan negatif terhadap efisiensi operasional perusahaan sementara Hanousek dan Svejnar (2004) menyimpulkan privatisasi tidak signifikan berhubungan dengan efisiensi operasional perusahaan.

Variabel yang ketiga adalah tingkat output, tingkat output mengalami peningkatan setelah perusahaan melakukan privatisasi (Chong et.al, 2003; Tran, 2008). Sementara Bozo, Machichado, dan Capra (2003) mendokumentasikan penurunan output setelah privatisasi. Hal ini terjadi karena pemerintah memberikan subsidi penjualan BUMN, dan setelah privatisasi BUMN mengurangi supply untuk barang bersubsidi.

Variabel keempat adalah tenaga kerja, jumlah tenaga kerja yang produktif pada perusahaan meningkat setelah privatisasi, sehingga berkurangnya kelebihan tenaga kerja, selain itu privatisasi bukanlah penyebab bertambahnya penggangguran massal, hal ini dikarenakan tingkat signifikansi pengurangan tenaga kerja pada BUMN yang sudah diprivatisasi lebih kecil dibandingkan tingkat signifikansi pengurangan tenaga kerja pada BUMN murni, walaupun pengurangan tenaga kerja adalah hal yang biasa dilakukan untuk meningkatkan efisiensi tenaga kerja (Huang dan Yao, 2006; Chong et.al, 2003; Tran, 2008; Torero, 2003; Bozo, Machicado, dan Capra (2003), namun privatisasi tidak signifikan berhubungan dengan kenaikan gaji rata-rata. Bozo, Machicado, dan Capra (2003) menyimpulkan bahwa privatisasi bukan merupakan penyebab kenaikan gaji rata-rata pada BUMN.

Variabel yang kelima adalah investasi. Penurunan aset tetap signifikan pada perusahaan setelah privatisasi, menggunakan rasio investment over sales dan rasio investment over fixed assets sebagai alat ukur pertumbuhan investasi (Bozo, Machicado, dan Capra, 2003; Galiani, Gertler, Schargrodsky, dan Sturzenegger, 2003; Galiani, Gertler, Schargrodsky, dan Sturzenegger, 2003). Sedangkan menurut Huang dan Yao (2006) tidak terdapat hubungan yang signifikan antara privatisasi terhadap tingkat investasi.

Variabel keenam adalah solvabilitas. Terdapat hubungan signifikan positif privatisasi dengan solvabilitas diukur dengan rasio utang sebagai alat ukur dan diuji dengan Wilcoxon signed-rank test (Tran, 2008),. Sebaliknya, Bozo, Machicado, dan Capra (2003) menemukan hubungan yang signifikan negatif antara privatisasi terhadap solvabilitas yang dibuktikan dengan penurunan log utang.

Variabel ketujuh adalah net taxes. Net taxes dapat mengevaluasi sejauh mana privatisasi mengubah jumlah pendapatan negara yang berasal dari penerimaan pajak. Tidak terdapat hubungan yang 
signifikan antara privatisasi BUMN terhadap perubahan jumlah pendapatan negara yang berasal dari penerimaan pajak, walaupun jumlah penerimaan pajak yang diperoleh dari BUMN mengalami peningkatan setelah privatisasi (Bozo, Machicado, dan Capra, 2003).. Sedangkan Bai, Lu, dan Tao (2007) menyimpulkan bahwa privatisasi perusahaan hanya memiliki hubungan yang signifikan dan positif terhadap penerimaan pajak pada perusahaan BUMN, namun memiliki hubungan yang tidak signifikan terhadap penerimaan pajak pada perusahaan non-BUMN.

Hasil-hasil yang bertentangan ini merupakan masalah yang menarik unruk diteliti seiring rencana menambah privatisasi perusahaan BUMN di Indonesia. Apakah privatisasi BUMN (Bank maupun non-bank) di Indonesia signifikan mempengaruhi peningkatan profitabilitas, efisiensi operasional, output, tenaga kerja, investasi, solvabilitas, dan net taxes.

\section{LANDASAN TEORI}

Keputusan IPO yang optimal memberi pembelajaran yang baik tentang profitabilitas rata-rata perusahaan swasta. Pertimbangan Pengusaha melakukan diversifikasi kepemilikan (IPO) yaitu berupa pertukaran antara manfaat kendali pribadi dengan manfaat go public. Bila go public sudah optimal profitabilitas masa depan yang diharapkan perusahaan cukup tinggi. Namun menurut model yang dikembangkan Pastor et al. (2007) ternyata rata-rata profitabilitas perusahaan setelah IPO menurun, dan penurunan ini seharusnya lebih besar bagi perusahaan yang lebih mudah berubah profitabilitasnya dan bagi perusahaan yang profitabilitas rata-ratanya tidak pasti. Prediksi ini didukung secara empiris dalam sampel 7.183 IPO di A.S. antara tahun 1975 - 2004 (Lubos Pastor, Lucian Taylor, dan Pietro Veronesi, 2006). Waktu krisis keuangan melanda dunia, perbankan dunia sangat terpukul. Akibat krisis tersebut beberapa bank komersial besar di Tiongkok telah muncul sebagai pemenang, berkat reformasi yang telah dilakukan mereka selama 10 tahun terakhir. Reformasi yang paling signifikan sebelum krisis adalah diversifikasi kepemilikan, yang bertujuan untuk memperbaiki tata kelola perusahaan dan efisiensi. Dalam satu tahun sejak Oktober 2005, tiga dari empat bank BUMN terbesar tercatat di bursa efek. Apakah reformasi ini benar-benar meningkatkan efisiensi bank. Mengadopsi pendekatan DEA (data envelopment analysis), IPO (penawaran umum perdana) efektif dalam meningkatkan kinerja bank. Hasilnya menunjukkan bahwa rata-rata, efisiensi bank meningkat hampir 10\% setelah IPO. Meskipun bank campuran (JEBs) masih berkinerja lebih baik daripada bank pemerintah. Bank pemerintah berhasil mengejar dan mengurangi kesenjangan efisiensi dengan bank campuran dalam beberapa tahun terakhir. Hal ini menjelaskan mengapa sistem perbankan China kurang terpengaruh oleh krisis keuangan dunia saat ini daripada rekan-rekan di negara bagian barat mereka. Reformasi bank pemerintah di China selama 10 tahun terakhir telah menghasilkan hasil yang luar biasa.

Transaksi korup hingga penyalahgunaan kekuatan pasar dan kehilangan kesejahteraan social membuat BUMN tidak efisien. Tujuan BUMN sebagai pelayan masyarakat inilah yang kemudian di perkirakan menjadikan praktek usaha tujuan profit dilakukan sebagai tujuan sampingan.

Sumber peningkatan profitabilitas BUMN setelah privatisasi diharapkan karena penyalahgunaan kekuatan pasar umum, eksploitasi pekerja dan kurangnya pajak pendapatan.

Transparansi dan homogenitas dalam prosedur, kecepatan, dan restrukturisasi terbatas sebelum privatisasi menghasilkan hasil yang lebih baik dan lebih sedikit ruang untuknya korupsi dan mengatur kebijaksanaan. Akhirnya, keberhasilan privatisasi ditingkatkan dua kebijakan pelengkap: re-regulasi atau deregulasi industri yang sebelumnya terlindungi dari kekuatan kompetitif; dan kerangka kerja tata kelola perusahaan yang efektif yang memudahkan akses perusahaan yang diprivatisasi terhadap modal dengan biaya lebih rendah. Privatisasi menyebabkan peningkatan profitabilitas dan produktivitas, restrukturisasi perusahaan, manfaat fiscal, 
pertumbuhan output dan bahkan peningkatan kualitas. Sebagian besar kasus kegagalan privatisasi dapat dikaitkan dengan buruknya desain kontrak, proses buram dengan keterlibatan pemerintah, kurangnya pengaturan ulang regulasi dan kerangka kerja tata kelola perusahaan yang buruk (Chong et.al, 2003).

Privatisasi mengarah pada perubahan penting dalam sifat dan struktur kepemilikan perusahaan maupun personil manajemen, yang pada gilirannya secara signifikan mempengaruhi kinerja perusahaan yang diprivatisasi. Persaingan yang dihasilkan dari pembukaan pasar luar negeri berpengaruh signifikan dan positif terhadap kinerja perusahaan yang diprivatisasi. Privatisasi yang masih mengandalkan bank komersial sebagai sumber utama pemberian kredit untuk aktivitas mereka seringkali masih mengandalkan jaminan pemerintah sehingga mendapatkan pinjaman dengan bunga yang rendah (Tran, 2006).

Privatisasi secara garis besar ( di Tiongkok, Africa, Asia, Latin America, Eastern and Western Europe, Vietnam, Nigeria, Peruvian, Bolivia, Amerika, Bulgaria, Romania, dan Argentina) meningkatkan profitabilitas, efisiensi operasional, investasi, output, dan tingkat solvabilitas, karena perubahan pola pikir seluruh karyawan dapat terjadi setelah dilakukan IPO. Pimpinan berhasil mengarahkan karyawan termotivasi untuk berorientasi profit. Namun ada beberapa yang belum berhasil mengubah pola pikir mereka dari institusi sector public menjadi bertanggung jawab kepada privat.

\section{Hipotesis}

$\mathrm{H}_{1}=$ Privatisasi signifikan mempengaruhi peningkatan profitabilitas pada BUMN non-bank (netprofit margin, return on eq uity, return on asset) dan Bank BUMN (net interest margin, return on equity, return on asset) di Indonesia.

$\mathrm{H}_{2}=$ Privatisasi signifikan mempengaruhi peningkatan efisiensi operasional pada BUMN nonbank (total assets turnover) dan Bank BUMN (Biaya Operasional Pendapatan Operasional) di Indonesia.

$\mathrm{H}_{3}=$ Privatisasi signifikan mempengaruhi peningkatan investasi (total investment) pada BUMN non-bank dan Bank BUMN di Indonesia.

$\mathrm{H}_{4}=$ Privatisasi signifikan mempengaruhi peningkatan output pada BUMN non-bank (total sales) dan Bank BUMN (loan growth) di Indonesia.

$\mathrm{H}_{5}=$ Privatisasi signifikan mempengaruhi peningkatan solvabilitas (debt to equity) pada BUMN non-bank dan Bank BUMN di Indonesia.

\section{METODE PENELITIAN \\ Operasionalisasi Variabel}

\section{Privatisasi}

Privatisasi adalah penjualan sebagian saham BUMN atau aset kepada sektor swasta. Privatisasi dalam penelitian ini merupakan variabel dummy, penulis menggunakan nilai 0 untuk masa sebelum privatisasi dan nilai 1 untuk masa setelah privatisasi. Tahun ke-0 tidak dimasukkan ke dalam penelitian ini.

\section{Profitabilitas}

Profitabilitas dalam penelitian ini diukur dengan menggunakan rasio profitabilitas, yaitu:

\section{a. Net Profit Margin (NPM)}

Indikator NPM sebagai berikut:

$$
N P M=\frac{\text { Net income available to common stock }}{\text { Sales }}
$$


b. Net Interest Margin (NIM)

c.

d. Return on Assets (ROA)

$$
N I M=\frac{\text { Pendapatan bunga-biaya bunga }}{\text { Total aktiva }}
$$

Indikator ROA sebagai berikut:

e. Return on Equity (ROE)

$$
R O A=\frac{\text { Net income available to common stock }}{\text { Total Asesets }}
$$

Indikator ROE sebagai berikut:

$$
R O E=\frac{\text { Net income available to common stock }}{\text { Total Common Equity }}
$$

\section{Efisiensi Operasional}

Merupakan rasio efisiensi adalah rasio yang digunakan untuk mengukur seberapa efektif perusahaan mengatur aktivanya menjadi penjualan atau kas. Total Assets Turnover (TATO) pada BUMN non-bank dan Biaya Operasional Pendapatan Operasional (BOPO) pada BUMN berbentuk perbankan digunakan untuk mengukur tingkat efisiensi operasional.

a. Total Assets Turnover (TATO)

Indikator TATO sebagai berikut:

$$
T A T O=\frac{\text { Sales }}{\text { Total Assets }}
$$

\section{b. Biaya Operasional Pendapatan Operasional (BOPO)}

Indikator BOPO sebagai berikut:

$$
\text { BOPO }=\frac{\text { Total Biaya Operasi }}{\text { Total Pendapatan Operasi }}
$$

\section{Output}

Output adalah barang jadi dan jasa sebagai hasil dari kegiatan produksi dan operasi, yaitu melalui kegiatan yang mentransformasikan masukan (input) dengan menciptakan nilai.

Penelitian ini menggunakan log of sales pada perusahaan non-bank dan menggunakan loan growth pada perusahaan perbankan sebagai alat ukur pertumbuhan output sebelum dan setelah privatisasi.

\section{a. Total sales}

Indikator output pada perusahaan non-banksebagai berikut:

\section{b. loan growth(\%)}

$$
\text { Output }=\text { Total Sales }
$$

Galiani, Gertler, Schargrodsky, dan Sturzenegger (2003:26) dalam penelitiannya terhadap privatisasi BUMN di Argentina menggunakan loan growth (\%)sebagai alat ukur pertumbuhan output setelah privatisasi. Indikator loan growth (\%)sebagai berikut:

$$
\text { Loan growth }(\%)=\frac{\text { Loan } t-\text { loan } t-1}{\text { Loan } t-1} \times 100 \%
$$

\section{Investasi}


Investasi adalah bentuk pengeluaran penanaman modal untuk membeli barang modal dan perlengkapan-perlengkapan produksi untuk menambah kemampuan produksi perusahaan atau dengan tujuan mendapatkan keuntungan dari kenaikan nilai objek tersebut selama jangka waktu investasi dan memperoleh hasil yang teratur selama jangka waktu investasi, biasanya dalam jangka waktu lama. Penelitian ini menggunakan Totalinvestmentsebagai alat ukur investasi. Indikator investmentsebagai berikut:

\section{Solvabilitas}

\section{Investasi $=$ Total investasi}

Solvabilitas/leverage adalah kemampuan jangka panjang perusahaan untuk melunasi atau memenuhi kewajiban-kewajiban yang digunakan sebagai sumber pembiayaannya yang telah jatuh tempo.

Solvabilitas yang digunakan dalam penelitian ini diukur dengan Debt to EquityRatio (DER). Indikator DER sebagai berikut:

$$
D E R=\frac{\text { Total Debt }}{\text { Total Equity }}
$$

\section{Teknik Analisis Data}

Model regresi variabel dummy adalah sebagai berikut:

Keterangan:

$$
\mathrm{Y}=\mathrm{a}+\mathrm{bD}+\varepsilon
$$

$\mathrm{Y}=$ Nilai yang diramalkan

a $=$ Konstansta

$\mathrm{b}=$ Koefisien regresi untuk Di

$\mathrm{D}_{\mathrm{i}}=$ Variabel Dummy dengan dua kategori, yaitu: $0=$ masa sebelum privatisasi; $1=$ setelah

$\varepsilon=$ Nilai Residu

\section{ANALISIS DAN PEMBAHASAN}

\section{Model Regresi Variabel Dummy BUMN Non-Bank}

Dengan menggunakan program Eviews 7.0, berikut adalah rangkuman hasil (output) yang diperoleh dari model regresi variabel dummy masing-masing variabel penelitian pada BUMN nonbank:

Tabel 1

Rangkuman Model Regresi Variabel Dummy BUMN Non-Bank

\begin{tabular}{|l|c|l|c|}
\hline \multicolumn{1}{|c|}{ Variabel } & Dimensi Variabel & \multicolumn{1}{c|}{$\begin{array}{c}\text { Model Regresi Variabel } \\
\text { Dummy }\end{array}$} & F-statistik \\
\hline \multirow{3}{*}{ Profitabilitas } & ROA & $\mathrm{Y}_{1}=0,4601-4,0058 \mathrm{D}$ & 0,0521 \\
\cline { 2 - 4 } & $\mathrm{ROE}$ & $\mathrm{Y}_{2}=0,9375-13,4117 \mathrm{D}$ & 0,0037 \\
\cline { 2 - 4 } & $\mathrm{NPM}$ & $\mathrm{Y}_{3}=0,1455+0,0176 \mathrm{D}$ & 0,7495 \\
\hline $\begin{array}{l}\text { Efisiensi } \\
\text { Operasional }\end{array}$ & TATO & $\mathrm{Y}_{4}=-0,9617+0,8913 \mathrm{D}$ & 0,5806 \\
\hline Investasi & Total Investment & $\mathrm{Y}_{5}=-0,0724+0,8129 \mathrm{D}$ & 0,0004 \\
\hline Output & Total Sales & $\mathrm{Y}_{6}=0,0701+0,4010 \mathrm{D}$ & 0,0042 \\
\hline Solvabilitas & DER & $\mathrm{Y}_{7}=-0,0718-0,6899 \mathrm{D}$ & 0,0056 \\
\hline
\end{tabular}

Sumber: Olahan Penulis dengan Eviews 7.0

\section{a. Privatisasi Mempengaruhi Profitabilitas (ROA, ROE, dan NPM)}


Sebelum privatisasi, ROA sebesar 0,4601\%. Sementara itu, ketika BUMN non-bank melakukan privatisasi, maka ROA akan menurun sebesar 4,0058 \%, dan dengan tingkat kepercayaan 95\% pengaruhnya negatip tidak signifikan $(\alpha=0,0521)$.

Ketika BUMN non-bank belum melakukan privatisasi, maka ROE adalah sebesar 0,9375\% Sementara itu, ketika BUMN non-bank melakukan privatisasi, maka ROE akan menurun sebesar $13,4117 \%$, dengan tingkat kepercayaan $95 \%$ pengaruh negatip ini signifikan $(\alpha=0,0037)$

Ketika BUMN non-bank belum melakukan privatisasi, maka NPM yang terjadi adalah sebesar 0,1455. Sementara itu, ketika BUMN non-bank melakukan privatisasi, maka NPM akan meningkat sebesar $0,0176 \%$, dengan tingkat kepercayaan $95 \%$ pengaruh positip ini tidak signifikan $(\alpha=0,7495)$.

\section{b. Privatisasi Mempengaruhi Efisiensi Operasional (TATO)}

Ketika BUMN non-bank belum melakukan privatisasi, maka TATO yang terjadi adalah sebesar 0,9617\%. Sementara itu, ketika BUMN non-bank melakukan privatisasi, maka TATO akan meningkat sebesar $0,8913 \%$, dengan tingkat kepercayaan $95 \%$ pengaruh positip ini tidak signifikan $(\alpha=0,5806)$..

\section{c. Privatisasi Mempengaruhi Investasi (Total Investment)}

Ketika BUMN non-bank belum melakukan privatisasi, maka total investment yang terjadi adalah sebesar -0,0724. Sementara itu, ketika BUMN non-bank melakukan privatisasi, maka total investmentakan meningkat sebesar 0,8129\%, dengan tingkat kepercayaan 95\% pengaruh positip ini signifikan $(\alpha=0,0004)$.

\section{d. $\quad$ Privatisasi Mempengaruhi Output (Total Sales)}

Ketika BUMN non-bank belum melakukan privatisasi, maka total sales yang terjadi adalah sebesar 0,0701. Sementara itu, ketika BUMN non-bank melakukan privatisasi, maka total sales akan meningkat sebesar $0,4010 \%$, dengan tingkat kepercayaan 95\% pengaruh positip ini signifikan $(\alpha=0,0042)$.

\section{e. $\quad$ Privatisasi Mempengaruhi Solvabilitas (DER)}

Ketika BUMN non-bank belum melakukan privatisasi, maka DER yang terjadi adalah sebesar 0,0718. Sementara itu, ketika BUMN non-bank melakukan privatisasi, maka DER akan menurun sebesar $0,6899 \%$, dengan tingkat kepercayaan $95 \%$ pengaruh negatip signifikan $(\alpha=0,0056)$.

\section{Model Regresi Variabel Dummy BUMN Berbentuk Perbankan}

Tabel 2.

Rangkuman Model Regresi Variabel Dummy BUMN Berbentuk Perbankan

\begin{tabular}{|l|c|l|c|}
\hline \multirow{2}{*}{ Variabel } & Dimensi Variabel & $\begin{array}{c}\text { Model Regresi Variabel } \\
\text { Dummy }\end{array}$ & F-statistik \\
\hline \multirow{3}{*}{ Profitabilitas } & NIM & $\mathrm{Y}_{8}=-0,0001+0,0029 \mathrm{D}$ & 0,9011 \\
\cline { 2 - 4 } & ROE & $\mathrm{Y}_{9}=-1,7987-1,1188 \mathrm{D}$ & 0,7322 \\
\cline { 2 - 4 } & ROA & $\mathrm{Y}_{10}=0,0202+0,4357 \mathrm{D}$ & 0,1185 \\
\hline Efisiensi Operasional & BOPO & $\mathrm{Y}_{11}=-1,1786+26,398 \mathrm{D}$ & 0,5619 \\
\hline Output & Loan Growth $(\%)$ & $\mathrm{Y}_{12}=24,785-13,6991 \mathrm{D}$ & 0,3274 \\
\hline Solvabilitas & DER & $\mathrm{Y}_{13}=0,9425+0,0383 \mathrm{D}$ & 0,5736 \\
\hline
\end{tabular}

Sumber: Olahan Penulis dengan Eviews 7.0

\section{Privatisasi Mempengaruhi Profitabilitas (NIM, ROE, ROA)}

Ketika BUMN berbentuk perbankan belum melakukan privatisasi, maka NIM yang terjadi adalah sebesar -0,0001. Sementara itu, ketika BUMN berbentuk perbankan melakukan privatisasi, maka 
NIM akan meningkat sebesar 0,0029 \%, dengan tingkat kepercayaan 95\% pengaruhnya positip tidak signifikan $(\alpha=0,9011)$.

Ketika BUMN berbentuk perbankan belum melakukan privatisasi, maka ROE yang terjadi adalah sebesar -1,7987. Sementara itu, ketika BUMN berbentuk perbankan melakukan privatisasi, maka ROE akan menurun sebesar $1,1188 \%$, dengan tingkat kepercayaan 95\% pengaruhnya negatip tidak signifikan $(\alpha=0,7322)$.

Ketika BUMN berbentuk perbankan belum melakukan privatisasi, maka ROA yang terjadi adalah sebesar 0,0202. Sementara itu, ketika BUMN berbentuk perbankan melakukan privatisasi, maka ROA akan meningkat sebesar $0,4357 \%$, dengan tingkat kepercayaan 95\% pengaruhnya positip tidak signifikan $(\alpha=0,1185)$.

\section{Privatisasi Mempengaruhi Efisiensi Operasional (BOPO)}

Ketika BUMN berbentuk perbankan belum melakukan privatisasi, maka BOPO yang terjadi adalah sebesar -1,1786. Sementara itu, ketika BUMN berbentuk perbankan melakukan privatisasi, maka BOPO akan meningkat sebesar $26,398 \%$, dengan tingkat kepercayaan $95 \%$ pengaruhnya positip tidak signifikan $(\alpha=0,5619)$.

\section{Privatisasi Mempengaruhi Output (Loan Growth)}

Ketika BUMN berbentuk perbankan belum melakukan privatisasi, maka loan growth sebesar 24,785\%. Sementara itu, ketika BUMN berbentuk perbankan melakukan privatisasi, maka loan growth menurun sebesar 13,6991\%, dengan tingkat kepercayaan 95\% pengaruhnya negatip tidak signifikan $(\alpha=0,3274)$.

\section{Privatisasi Mempengaruhi Solvabilitas (DER)}

Ketika BUMN berbentuk perbankan belum melakukan privatisasi, maka DER yang terjadi adalah sebesar 0,9425. Sementara itu, ketika BUMN berbentuk perbankan melakukan privatisasi, maka DER akan meningkat sebesar 0,0383 , dengan tingkat kepercayaan $95 \%$ pengaruhnya positip tidak signifikan $(\alpha=0,5736)$.

\section{PEMBAHASAN \\ BUMN Non-Bank}

Secara umum, privatisasi menurunkan signifikan kinerja ROE namun tidak signifikan kinerja ROA BUMN non-bank. Konsisten dengan Bozo, Machicado, dan Capra (2003) bahwa privatisasi tidak signifikan mempengaruhi profitabilitas perusahaan. Profitabilitas perusahaan yang berasal dari penjualan dan penggunaan aktiva perusahaan tidak signifikan meningkat namun signifikan bila dilihat dari kemampuan perusahaan memperoleh laba melalui efektifitas perusahaan menggunakan kontribusi pemilik dan sumber-sumber lain untuk kepentingan pemilik. Hal ini disebabkan karena dibutuhkan lebih banyak variabel kontrol makroekonomi dan faktor eksternal lainnya yang dapat mempengaruhi profitabilitas. Konsisten dengan hasil penelitian Pastor, Taylor, dan Veronesi (2006) dan Clementi (2002) privatisasi mempunyai hubungan negatif terhadap profitabilitas perusahaan. Penurunan profitabilitas yang lebih besar terjadi pada perusahaan yang memiliki ketidakpastian yang tinggi dan perputaran yang lebih rendah.

Tidak ditemukan hubungan yang signifikan privatisasi dengan efisiensi operasional. Hasil ini konsisten dengan hasil penelitian Hanousek dan Svejnar (2004), dan tidak konsisten dengan Huang dan Yao (2006). Bahwa efisiensi perusahaan menurun setelah melakukan privatisasi. Efisiensi operasional yang menurun ini diperkirakan karena pada awal periode setelah privatisasi, perusahaan mengalokasikan lebih banyak biaya untuk pembaharuan sistem operasi dibandingkan biaya untuk menghasilkan pendapatan operasional. Selain itu perusahaan mungkin masih memakai 
sistem operasi yang sama seperti periode sebelum privatisasi, sehingga tidak terdapat hubungan yang signifikan antara privatisasi dengan efisiensi operasional.

Investasi pada perusahaan meningkat setelah privatisasi (Bozo, Machicado, dan Capra, 2003; Galiani, Gertler, Schargrodsky, dan Sturzenegger, 2003). Peningkatan investasi disebabkan karena setelah perusahaan melakukan privatisasi, perusahaan berusaha untuk meningkatkan efisiensi operasional perusahaan dengan menjual aset tetap yang tidak efisien dan memperbaharui sistem produksi agar menjadi lebih menguntungkan dan menghilangkan tahapan yang tidak menguntungkan. Lalu kemudian, perusahaan membeli aset tetap yang dapat meningkatkan efisiensi perusahaan sehingga investasi perusahaan dalam bentuk aset tetap meningkat.

Privatisasi menyebabkan penurunan signifikan output konsisten dengan Bozo, Machicado, dan Capra (2003) dan tidak konsisten dengan Chong et.al (2003) dan Tran (2008). Hal ini disebabkan karena setelah perusahaan melakukan privatisasi, sebagian sumber pendanaan perusahaan beralih dari hutang bank ke saham, sehingga pada awal privatisasi hutang perusahaan menurun. Untuk menarik minat para calon investor, ada kemungkinan pemerintah mengasumsikan hutang yang lebih rendah dari keadaan sebenarnya sebelum perusahaan melakukan privatisasi. Hal ini dilakukan agar jumlah saham yang dilepas kepada pihak swasta habis terjual dan target jumlah pengumpulan dana terpenuhi.

\section{BUMN Berbentuk Perbankan}

Secara keseluruhan, privatisasi tidak signifikan mempengaruhi kinerja BUMN berbentuk perbankan. Hal ini tidak konsisten dengan Beck, Cull, dan Jerome (2005) yang menemukan privatisasi signifikan terhadap profitabilitas perusahaan. Hal ini mungkin disebabkan karena bank memutuskan untuk melakukan privatisasi berdasarkan seberapa baik kinerja bank pada saat sebelum melakukan privatisasi. Bank mungkin saja dapat melakukan manipulasi data akuntasinya untuk meningkatkan profitabilitas sebelum melakukan privatisasi.

Privatisasi menyebabkan penurunan tidak signifikan efisiensi operasional Hasil ini konsisten dengan hasil penelitian Bonin, Hasan, dan Wachtel (2004). Hal ini mungkin diakibatkan oleh tidak adanya atau kurangnya kepemilikan asing dan partisipasi institusi investor asing pada perusahaan. Dengan adanya kepemilikan asing dan partisipasi institusi investor asing, perusahaan mampu menyediakan deposit dan pinjaman yang lebih banyak dengan biaya yang lebih rendah sehingga mampu menyediakan jasa yang lebih baik daripada kepemilikan domestik.

Privatisasi menyebabkan penurunan tidak signifikan output, dan tidak konsisten dengan Bozo, Machicado, dan Capra(2003) yang menemukan bahwa tingkat output mengalami penurunan signifikan setelah perusahaan melakukan privatisasi. Penurunan tingkat outputini salah satunya disebabkan oleh penurunan efisiensi operasional dan karena bantuan pemerintah selama sebelum privatisasi kepada BUMN dikurangi atau dihilangkan setelah privatisasi.

Privatisasi menurunkan tidak signifikan solvabilitas, tidak konsisten dengan Tran (2008). Hal ini mungkin disebabkan karena dana yang diperoleh dari pasar modal belum cukup untuk membiayai perusahaan, sehingga perusahaan tetap menggunakan pinjaman bank komersial atau pinjaman pemerintah sebagai sumber pembiayaanya. Sedangkan profitabilitas perusahaan menurun setelah melakukan privatisasi, sehingga menyebabkan penurunan kemampuan perusahaan dalam melunasi kewajiban-kewajibannya.

\section{DAFTAR PUSTAKA}

Albornoz, Belén Gill de Albornoz danPope, Peter F. (2004). The determinants of the going public decision: evidence from the U.K. WP-AD 2004-22 
Bai, Chong-En,Lu, Jiangyong, dan Tao Zhigang. (2007). How does privatization work in china?MPRA paper. No. 6599

Beck, Thorsten, Cull, Robert, dan Jerome, Afeikhena. (2005). Bank privatization and performance empirical evidence from nigeria.World Bank policy research working paper. WPS3511

Bonin, John P., Hasan, Iftekhar, dan Wachtel, Paul. (2004). Bank performance, efficiency and ownership in transition countries. BOFIT Discussion Papers. No. 7

Bornstein, Morris. (2000). Post-Privatization Enterprise Restructuring. Working Paper Number 327

Bozo, Mauricio Garrón, Machicado, Carlos Gustav, dan Capra, Katherina. (2003). Privatization in bolivia: the impact on firm performance.latin american research network project "costs and benefits of privatization in latin america. "'Research Network Working Paper \#R-461

Chase, Richard B., Jacobs, F. Robert, dan Aquilano, Nicholas J. (2004). Operating management for competitive advantage. Edisi kesepuluh. New York: McGraw-Hill Companies, Inc

Chong, Alberto dan Galdo, Virgilio.(2003). Should state-owned firms chang CEOs before privatization? the case of the telecommunications industry. Working Paper \#481

Clementi, Gian Luca. (2002). IPOs and The Growth of Firms. New York University: Department of Economics, Stern School of Business,.

Galiani, Sebastián, et.al. (2003). The costs and benefits of privatization in argentina: $a$ microeconomic analysis. Research Network Working Paper \#R-454

Halkos, George dan Salamouris, Dimitrios S. (2002). State owned enterprises, privatization and the public interest: evidence of S.O.E. performance in the greek manufacturing. MPRA Paper No. 39604

Hanousek, Jan, Kočenda, Evzen, dan Švejnar, Jan. (2004). Ownership, Control and Corporate Performance After Large-Scale Privatization.William Davidson Institute Working Paper Number 652

. (2005). Origin and Concentration: Corporate Ownership, Control and Performance. Workingpaper series (ISSN 1211-3298). Vol 259Helfert,

Huang, Lingwendan Yao, Yang.(2006). Impacts of privatization on employment: evidence from china. NO. E2006008. China: China Center for Economic Research, Peking University.

Jain, Bharat A. dan Kini, Omesh Kini. (2008). The impact of strategic investment choices on postissue operating performance and survival of US IPO firms.Journal of business finance \& accounting. Hal 459-490

Katz, Sharon. (2008). Earnings quality and ownership structure: the role of private equity sponsors. NBER Working Paper No. 14085

Konings, Jozef, Cayseele, Patrick Van, dan Warzynski, Frederic. (2002). The effects of privatization and competitive pressure on firms' price-cost margins: micro evidence from emerging economies.LICOS discussion papers. Vol 125

Lopez-de-Silanes, Florencio,dan Chong, Alberto. (2003). The truth about privatization in latin america. Yale ICF Working Paper No. 03-29

Luo, Dan dan Yao, Shujie. (2009). World financial crisis and the rise of chinese commercial banks.Research Paper Series: China and The World Economy. Hal 7

McGraw, Patricia A.(2005). Privatization and the corporate cost of capital in new zealand: an application of fama and french (1999). Review of Applied Economics. Vol.1, No.1.

Omran, Mohammed. (2009). Post-privatization corporate governance and firm performance: the role of private ownership concentration, identity and board composition. Working Paper No.495

Pastor, Lubos, Taylor, Lucian, dan Veronesi Pietro. (2006). Entrepreneurial learning, the IPO decision, and the post-IPO drop in firm profitability. Working Paper 12792 
Quan, Qi dan Huyghebaert, N. (2004). Privatization: issues at stake in the case of china. Tijdschrift voor economie en management. Vol. XLIX

Rosen, Richard J., Smart, Scott B. Smart, dan Zutter, Chad J.(2005). Why Do Firms Go Public? Evidence from the Banking Industry. WP 2005-17

Shelor, Roger M. dan Anderson, Dwight C. (1998). The financial performance of REITs following initial public offerings. Journal of real estate research. Vol 16. Hal 375-387

Torero, Máximo. (2003). Peruvian privatization: impacts on firm performance. latin american research network project "costs and benefits of privatization in latin america." Research Network Working Paper \#R-481

Tran, Giang. (2008). The impacts of corporate governance on the performance of privatized firmns in vietnam. 